\title{
The Effects of Packaging on Customer Purchasing Decision. (Melcom Ghana Limited)
}

\author{
Mr. Boadi Frederick Mensah Prof. Sijing Chen Huamin Hu \\ School of Economics and Management, Zhejiang University of Science and Technology, PR China
}

\begin{abstract}
This study's goal was to reveal the impact of produce packaging on customers' purchasing decisions in the municipality of Ho. Using Melcom as a case study, the study selected a total of 109 customers of about 150 employees, and on what benefits to convenience. When collecting data, respondents who were analyzed using SPSS using frequency evaluation and One-Way Chi-Square were provided with self-managed questionnaires to determine the number and percentage of respondents who consent to specific statements and to check the importance of those answers. The outcome indicated that the packaging affects product prices, which affects the customer's purchasing decision. The study also determined that labels and printed materials promote the company's products and these elements affect consumers' decisions to make before they buy a product. The results also showed how packaging contributes to the company's product. The results showed that good packaging leaves a positive image of goods with the consumers. Based on the results, we have advised that manufacturers also use innovative ways to make packaging more attractive and qualitative, as it affects customer purchasing decisions. It is also recommended that consumer products deliver with good packaging that leaves a positive picture in their minds, creating brand loyalty.
\end{abstract}

Keywords: consumer, customer, packaging, Melcom, shopping, promotion, products, purchasing

DOI: $10.7176 / \mathrm{JMCR} / 65-02$

Publication date: February $29^{\text {th }} 2020$

\section{Introduction}

In the current business environment, Packaging itself has become a sales promotion tool for organizations (Underwood, 2003). Most companies consider packaging as a confirmation root. This gives the consumer a first impression of buying products. Quality packaging attracts consumers' attention to new products (Alice, 2006). According to Belch and Belch (1999), the average supermarket in the United States contains about 20,000 products that compete to attract consumer attention. Keller (2008) made a similar statement when he explained that consumers have more than 20,000 options in a 30-minute shopping session. With many options before making a purchase decision, product packaging is a main marketing tools companies can use to sell products.

Unlike Europe and America, Africa is now making improvements in the packaging of its products. According to Schneider (2015), Africa has the most arable country suitable for agriculture than any other continent. This means that African countries with the right packaging and knowledge of the supply chain can expand their exports around the world. There are so many packaging in Central and West Africa throughout the African continent. This is where sellers buy wholesale and repackage in smaller quantities for "market" sales. For example, packaging must be delivered, assisted and assisted in this area.

According to Tette (2011), in Ghana, the issue of packaging is not different from what is happening on the African continent. This has been recognized as major reason for the inability of regional assets to compete positively with foreigners.

However, the packaging is part of planning and developing envelopes for the elements. Decision-making is a decision-making method used by customers regarding the transaction pre-market, during and after the service. The quick definition of a consumer purchase decision is the process that a customer goes through when they purchase an item or service.

The above discussion discusses the role that packaging plays in the decision to buy consumers. This means that there is a link to packaging and a consumer purchase decision. This is because the way products are packaged affects how consumers react to the product. Consumers will be willing to buy a well-packaged product that has a bad package. Manufacturers should therefore consider the important role of packaging in the placement of products on the market.

\section{Statement of the Problem}

This is an essential part of product advertising because it is really housing that includes products. Packaging is necessary to give information to consumers, depending on the shape of the product, however, many of the packaging problems may be related to labels, graphics, safety and the environment (Wu, 2014). According to Dancy (2010), the biggest problem with packaging, he argues that most companies focus on two priorities when it comes to packaging, which is how it will encourage consumers to see my product and how much it costs. For some, sustainability is the third and least important issue. For example, in Europe and America, despite the 
quality of packaging, some marketers tend to label their products as environmentally friendly. However, the products don't actually have environmental characteristics (Rettie and Brewer, 2006).

As noted by Dano and Odumten (2009), in Ghana, as in the African continent, most locally produced products cannot compete with imported products due to defective packaging. As a result, many African manufacturers are focused on reducing costs, so efforts simply reduce packaging, often with products that come in unattractive packaging. Thus, packaging is a more than economically sustainable investment option, but it is also vital for protection.

In Ho branch of Melcom Ghana there are several products ranging from electronics to furniture and shops, among other things. However, this is done through regular visits to the store that the store tends to sell goods on certain products, especially in the food and detergent department, while others are more on the shelves. An important distinction between products that sell easily and those that sit on shelves more than their packaging. At the same time, such products tend to serve the same purpose or the like. This will help us determine how packaging affects consumer protection at the Ho Melcom branch in Ghana.

\subsection{Research Questions}

1. How does packaging influence the price of produce?

2. What are the elements of packaging that influences customer purchasing decisions?

3. How does packaging promote the product of company?

\subsection{Significance of the Study}

In this modern era, competition has become keen and heavy in every business environment. Therefore, marketers are using various marketing strategies to outwit their competitors. Marketers are using packaging as means of advertising their products. In this study, importance is on the effect of packing on customer purchasing decision. Results in the end will give policy makers an insight on major problems encountered by businesses in the area of packaging. This will help them come up with appropriate policies to help producers improve upon their packaging while protecting the consumer as well.

It will also serve as a guide to the marketers to consider the elements of packaging that mostly influence consumer buying decision and also help them to have an economical benefit over their competitors. Findings will also serve as a source of reference for future studies for students and other researchers.

\subsection{Limitation of the study.}

In the context coverage, this study will be limited on the consequence of packaging on customer purchasing decision and how price influences the buying of a product. Geographically, the study will be limited to the Ho municipality. The shop is opposite the Ho sports stadium. Recently, lots of people have relocated to Ho due to the establishment of schools and both government and private businesses in the area. This has led to several shops being opened in the municipality, including Melcom, Stadium Gate Shopping Mall, God Dey, among others who deals in grocery, furniture and various household wares. Due to the large variety of goods being dealt in by Melcom, packaging has become an important factor considered by consumers whenever they shop.

\section{REVIEW OF RELATED LITERATURE}

\subsection{Overview}

The reviews of related literature on the concepts of branding and consumer purchase decision. It looks at how packaging impacts the price of a product, the elements of packaging that effects consumer purchasing decision, and how packaging promotes the products of a company.

\subsection{Definitions of Packaging and Consumer Purchase Decision \\ 2.2.1 Definitions of Packaging}

Panwar (2004), defined the packaging as an act of content, protection and presentation of content through the chain of manufacturing, transformation and transport to its destination in good condition, as it was, during production. The operational definition is related to the container containing the product. The may be of plastic, glass, metal or paper. This definition implies that, packing or wrapping is not simply concerned with the container of a product but also how it is preserved from production till it gets to the final consumer in a safe manner as it were from production.

Kotler (2006) defines packaging as all the activities for the design and manufacture of the container in a product. This definition looks at packaging as the outer packaging of a produce. However, wrapping is more than the container of a produce. It also involves the protection of a product from production till it gets to the final customer of the product. It's also to make a product effectively sellable as well as to guard it against damage and prevent it from damage whilst in storage.

Having reviewed the definitions above, this study would like to define packaging as the outer wrapper or 
container of a product that keeps the product clean, protects the product, and also makes it sellable to the consumer.

\subsubsection{Definitions of Consumer Purchase Decision}

Purchasing decision-making is a decision-making process that consumers have taken into the context of premarket transactions during and after (Peter s Olson, 1999). A prompt definition of a consumer's purchasing decision is the process that a customer goes through when buying an item or service.

The decision to buy a consumer relates to how consumers make judgments when choosing between alternatives (Powell, 2008). Pride and Ferrell (2014) stated that in order to understand the decision to buy consumers, the marketer need to appreciate the consumer process and the usefulness of products in consumer perception. This means that when buying products unconsciously, the customer goes a few steps in making a decision about buying, buying and after buying the valuation.

Due to the importance of this research, the decision to purchase the user will be defined as a number of options made by the consumer before buying the product.

\subsection{Theories of Packaging and Consumer Purchase Decision \\ 2.3.1 Theory of Brand Loyalty (1976)}

According to Buckley and Casson (1976), the theory of brand loyalty explains the relationship of customers' psychology with the brand of a company. According to this theory, the positive behaviour of a customer towards a brand has three different aspects: emotional attachment, brand evaluation, and behavioural aspect. The first aspect relates to the emotional attachment of customer with the brand. If this is positive, he will always be inclined to buy this product and will never go to even check other companies' products (Oakley, 2013).

The approach of loyalty-connected profitability also has its critics. Reinartz \& Kumar (2002) have found results proving that the link between loyalty and profits is much weaker. In their study they claim that to generalize long-term clients to be more profitable is a gross oversimplification since there is a lot of contradicting evidence especially in a non-contractual environment. They suggest caution and deeper analysis of customer profitability since some customers are very profitable in the beginning, but turn unprofitable at the end (Reinartz \& Kumar, 2002). It has been stated that loyal customers know its value and demand better service and spread positive words if they feel faithful (Kumar \& Rajan, 2009). Chegini (2010) also points out that, creating loyalty in all customers is not possible. Thus, to avoid serving the wrong customers the customers should be screened for profitability and served accordingly, by investing only in the most profitable relationships.

In relation to this study, the theory of brand loyalty is used to assess the brands that are regularly purchased by consumers whenever they visit the shop. This can be measured by how regular supplies of such brands are received as compared to same products of other brands. In this way, the credibility of the theory can be measured as to whether consumers being loyal and emotionally attached to a product is a guarantee of profitability.

Nevertheless, today's managers should understand that they must commit to relationship management, try to develop and maintain long-term relations with customers and making business strategies (Reichheld \& Schefter, 2010). It is also important to notice that, loyalty can be gained but marketers should act continuously on maintaining that loyalty.

\subsubsection{Distinctive Asset Theory}

According to the distinctive theory of wealth of Chamberslin and Robinson (1933), the distinctive asset is the distinctive feature of the brand, which differentiates it from other brand. Thismakes a positive asset for the brand because it is an element that consumers store the brand with and after it can easily remember the brand only by seeing this distinctive asset (Piero et al., 2010). In other words, the link between consumer memory and brand is the hallmark of product packaging. Thus, if you see it in the store, the products of a certain brand will be easier to recognize, so the brand is likely to be re-purchased if is a known and familiar to the consumer. Elements such as the colour and shape of the packaging have been proposed as a means of creating a distinctive character (Gaillard, 2007). This shows that a distinctive asset will have a more effect on the recognition and purchase of the product. Distinctive heritage also activators includes a branded product in the consumer's choice along with the time of choice or purchase (Romanuik and Sharp, 2004a).

In this study, distinctive asset theory can be applied by identifying products that consumers regularly ask for whenever they come to shop and don't. In such cases, consumers will not go for similar products from other brands if the store tries to replace the preferred brand with a similar one. This is because they unconsciously have the characteristics of their favorite brand imprinted in their memories. In this way, they can easily distinguish the sign from other similar ones.

However, Sharp and Dawes (2011) argue that differentiation, although a widely used aspect of modern markets, is largely a feature of the market. Competitive brands on the market differ equally with probable (small) infringements between small and large brands. Brands differ mainly in an individual purchasing situation, not at brand level. 


\subsection{How Packaging can Influences Price of a Product}

In many cases, this is the last listing a person will see for the product as they look through store shelves before deciding what to buy. Effective product packaging attracts attention in a positive way and encourages consumers to purchase (Foncel and Ivaldi, 2005). Thus, every marketer and entrepreneur should understand the power of packaging to stimulate sales. This is important part of the marketing plan for any company that manufactures or sells products. Product packaging can be a strong point for many consumers, offering a sense of quality and also reflects the brand image of the product. This is crucial in retail, where the correct packaging design can attract the consumer's attention and bring out the product next to a competitor's product stand (Lane, 2014).

For example, Young (2006) in his study found that packaging allows manufacturers to charge higher prices than if all products were considered identical to the consumer. He also said that making product packaging design attractive and completely unique to consumers to notice would increase the chances of converting packaging interest into actual sales. Thus, packaging design needs to be integrated into the vendor's product marketing strategy to create a significant impact on the customer's audience. Innovations in packaging and product labelling can also improve product profitability and customer demand. Chaneta (2012) found, however, that, there have been cases where consumers complain manufacturers sometimes end up charging high prices because of attractive packages. This may be due to the fact that manufacturers end up incuring high packaging costs, which they end up passing on to consumers.

Vernuccios (2010), according to him, when the products of all suppliers are the same, no company can raise the price above the prices of its competitors without losing all market share. However, when products are differentiated through packaging and consumers have several favorites for different products, companies can increase prices without losing their overall consumer base (Vernuccio, 2010). Thus, Vernuccio's results may make it difficult for companies to use differentiation to emphasize the attributes of a product that allows them to raise prices. Although packaging serves as a differencies in prices, the results of the Sajuyigbe et al. (2013) study have shown that manufacturers sometimes come with packages that sometimes end up confusing consumers. Confusion arises when customers end up providing different prices for products that in variety sizes.

Of the above, manufacturers can increase the price if their packaging is attractive and of high quality. The manufacturer's lack of ability to raise prices reduces the manufacturer's power. In the absence of attractive and high-quality packaging, consumers are more willing to move from one product to another. This will lead to competition focused on higher and lower prices. When this happens, there may be lower prices for the best brands. The price goes hand in hand with the packaging. The higher price paid by consumers should be clear to others that the consumer paid a lot for the product. Bad packaging will eliminate this capacity of consumers who pay for the product higher, despite their quality.

\subsection{Elements of Packaging that Promotes the Products of an Enterprise}

Packaging is considered to be a less expensive and an effective tool in marketing communications (Keller, 2009). To start with, printed information has been found by Barber et al. (2006) to be essential since they convey important information like marketing messages as well as ingredients or materials used in making a product. The labels also establish brand identity and enhance name recognition. According Sharp (2006), people buying for the first time, labels help establish brand identity and name recognition. The information printed on labels and packaging can easily impact the buying decision at the last minute, compelling him purchase a product or pass it by for another (Scriven \& Ehrenberg, 2004). In the fast moving consumer goods market where people spend little time evaluating a given product, it is very important for the package to provide the right information.

Rosen (2010) have however found packages of some products to have misleading information. He further stated that, often, products will have words such as fat free, low-fat, or organic on the labels. Labels such as these may misinformed the consumer into thinking to some degree that might not be the as it looks like For example, they may think there are no calories in a product, when in fact there are many.

Another element of packaging that promotes the produces of an enterprise is the packaging material. Burke (2006) found that, when quality materials are used for the packages of products, consumers will prefer such products. To buttress this point, Silayoi \& Speece (2004), high quality packaging labels will influence consumers to purchase more of a product than low quality packaging and labels. Packaging structure and materials however depend on several characteristics of the product itself, such as, the type of product, transportation conditions, storage, protection, target audience, or cost. The materials usually used for packaging include paper, plastics, glass, and metal.

For example, polyethylene et presented as a huge threat to the ecosystem, as it decomposes for many years. It usually ends up filling the oceans, poisoning wild animals and even clog waterways and drainage pipes that can cause flooding when there's rain. Cordell et al. (2006) also found that transporting glass is expensive weight, despite efforts to use thinner glass. Another problem et its disintegration and susceptible to rupture by internal pressure, exposure or heat shock.

Images are another packaging element that is often used as an effective design tool as a brighter stimulus 
than words (Underwood et al. 2001). As a rule, they are an image of the content of the package, with the aim not only of showing inside, but also causing desirability and interest. Sometimes images can represent brand-related graphics. Chuksovec (2010) in his study found that graphics have relationship between an image and a specific group of products, or it can also show a method of product development and production. If used correctly, this article can become a brand id and facilitate the recall of the product only from the images associated with it. Each packaging item transmits something, so the image projected from the packaging must match the image required for the product (O'Shaughnessy, 2005). All the information you need must be clearly visible or implicit through design.

However, measures need to be taken to reduce the negative impact of packaging. Misleading labels and materials that have a negative impact on the environment are removed in Quean. Indeed, Kwando consumers will develop a sense of trust and commitment to the product, which will ultimately lead to increased sales.

In these cases, the image on the product packaging y misleading to the customer.

From the above review, y clear that packaging is one a tools for marketing, which also serves as an influx factor in consumer choice. Therefore, companies provide effective use of packaging products that promote their products (printed information, materials, images, etc.) to attract the attention of consumers. However, measures must be taken to help reduce the negative effects of packaging.

\subsection{How Packaging Promotes the Products of a Company}

Packaging is a significant influencing factor to consumer buying decision (Miller, 2009). It has a huge impact on a company's success in a highly competitive environment. The role of packaging has changed due to the increase in self-service and the change in lifestyle in a competitive business environment

Packaging is a product packaging that contains information about the product and the manufacturer of a product (Rundh, 2005). This means that a package becomes an essential sales offer that stimulates motivating buying behavior, increases the market share of companies and reduces advertising costs. In this modern era, packaging is also used as a marketing tool to describe the product, increase the visibility of the product on the shelves and provide information to the customer (O’Shaughnessy, 2005).

To affirm the importance of packaging promoting the products of a company, Alexanders (2008) found that, a package attracts a buyer's attention to specific brand, boosts its image, and impacts the consumer's opinions about a product. Also, packaging tells distinctive value to products, helps consumers to select a items among a varied collection of alike stuff, and stirs a consumer's buying behaviour (Wells, et al., 2007). Lodhi \& Ahmed (2013) however found that, though packaging had an influence on the consumer buying behaviour, there are some other factors (price, place, promotion, and product) which also influence the consumer buying behaviour. Also, consumers are not inclined towards product that comes in poor packages. This affects reasons of wrapping as a product promotional tool.

Also, Kuvykaite (2009), a package catches a buyer's mind to a specific product and influence the consumer's purchase behaviour about product. A good packaging leaves a positive picture of the product in with the consumer. This implies that, packaging does not just serves a container holding products but also serves as means of communication of the product information to the consumer. Packaging must however serve its functional essences of guarding the products in storage, transferring and also in used. Another function is to give the customers ease of access and used for the tenacity of convenience.

Aside the importance of packaging to promote the products of a company, Saeed et al. (2013) found that, brand image doesn't provide a helpful connection with the purchase decision of a consumer. The investment of the brand was also considered to be a moderately positive relationship with the purchase decision. Packaging has also been shown to have a negative impact on the environment.

Due to the sophisticated nature of packaging products in recent times to attract more consumers, packaging and labelling has been found of producing a variety of excess waste that just receives thrown out as soon as the consumer has purchased the product. Producers must therefore make sure in the pursuit to endorse their produces, the right information is given to consumers concerning products. This is help them make knowledgeable decisions. Also, manufacturers must also have environmental sustainability in mind when choosing their packaging materials. This in a way will help ease the negative effects of packaging on the environment.

\subsection{Conclusions/ Conceptual Framework}

Packaging is tools in today's advertising and it has a great important effect on the consumer's buying behaviour. The review above throws more light on how these two variables interact. A product's package was identified as a sales point for most customers by bringing a sense of quality. This implies it will attracts a customer's eye and made the produce position out amid others. This will give producers the chance to increase the prices more than they would if the products were seen by the consumer as similar to that of competitors.

A product image, packaging materials, and printed information were identified as some of the elements that promotes the produces of enterprise. These communicate certain impressions and values of the items at the time 
of sale. Finally, in relation to how packaging promotes the products of a company, it was noted to attract a buyer's attention to a specific brand, boost its image, and impacts the consumer's view about the produce.

The above review is presented in the conceptual framework below, which is influenced by Chamberlin and Robinson's (1933) distinctive asset theory.

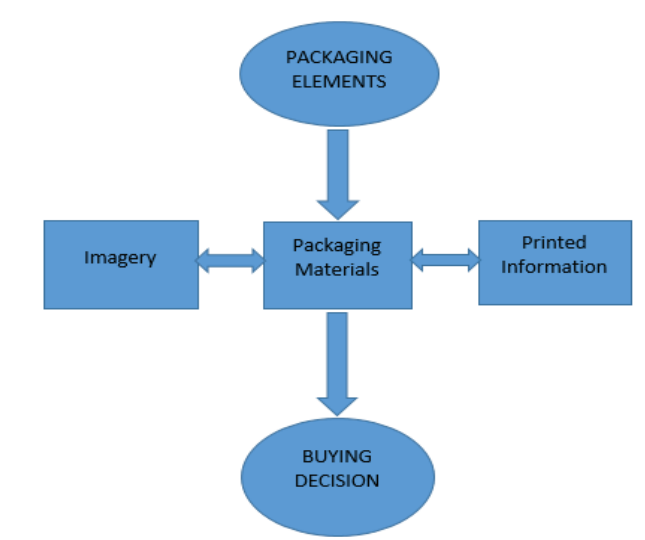

Figure 2.1: Conceptual Framework of Branding and Consumer Buying Decision

The framework above illustrates some of the elements of packaging and how they affect the buying decision of consumers. Images on a package attracts the attention of customers to a product. In such instances, a consumer may end up making a purchase though it was not initially planned for. Manufacturers must however make sure pictures used in packaging must depict the real product.

The resources used in wrapping is also another factor that influences a consumer to buy a product. These include glass, paper, plastic, aluminium, etc. Consumers tend to purchase products that have quality packaging materials. This is because they are more attractive and durable. Since one of the purposes of packaging is to draw attention of a consumer towards a product, producers must ensure the resources used in packaging underlines the uniqueness and originality of their products. They must however decrease the quantity of materials used in packaging in order to reduce waste and also engage in sustainable development practices such as recycling of waste materials to help in protecting the environment.

\subsection{METHODOLOGY}

\subsection{Introduction}

This part of the paper is the methodology of study that will be employed and also how the research will be conducted. The chapter therefore presents the study area, design of the study, population of the research, sampling and determination of sample size, sampling technique, data collection tools/instruments, data collection procedures and data analysis.

\subsection{Study area}

The study conducted in the Ho Municipality. Volta Region have twenty-five (25) Districts and Municipal Assemblies including the Ho Municipal, in which the Melcom Ltd is located. The municipality is enrich with many business such as mobile telecommunication companies hospitality set-ups (hotels, restaurants, guest houses etc) and many other shopping centers all in the services sector. It is therefore obvious that due to the dual role-played by Ho, it attracts the influx of various categories of people and triggers commercial activities that doubtlessly include those of the services sector. Due to the vast nature the municipality, the study chose Melcom customers as the study area.

The core focus of their business is retail department stores; however they are additionally highly positioned in wholesale and distribution due to the vast range of goods they stock. Their items include everything from household, electronics \& electrical, kitchen, plastic wares, travel goods, furniture, provisions, glassware, exercise $\&$ recreational equipment and more.

\subsection{Research Design}

This research employed the descriptive research design, under which case study was considered for the study. The main purpose of this study was that it enables the researcher to conduct a systematic enquiry into an event or helped the researchers determine the factors and relationships of related events which aim to describe and explain their interest.

\subsection{Population of study}

This study's population consisted of customers, employees and management of the Melcom Limited. It is 
heterogeneous because the customers are distinct from employees and that of management Melcom. The projected population size for this study including the customers, employees and management of the Melcom was 150. Customers were 130; employees and management staff 20. The customers are the consumers of Melcom Ltd items and facilities and employees and management are the people that form the organization's structure and perform all activities of Melcom.

\subsection{Sample Size Determination}

The projected population of this study for customers, general workers and management add up to 150 . According to the Robert V. Krejcie and Daryle W. Morgan (1970), when the population size is 150, the required sample size will be 14 at a margin of error of $0.05 \%$ with a confidence level of $95 \%$. In determining the sample size where the population is known, the following formula can be use.

$\mathrm{S}=\frac{\mathrm{NP}(1-\mathrm{P})}{(\mathrm{N}-1)+(1-\mathrm{P})}$

Where $\mathrm{S}=$ required sample size

$=$ Table value of Chi-Square for 1 grade of independence at the desired assurance level

$\mathrm{N}=$ population size

$\mathrm{P}=$ population proportion (assumed to be .05 )

$\mathrm{d}=$ degree of exactness stated as a percentage

Using a 95\% confidence level with an estimated population of 150 and a confidence interval of 0.05 , we will get a sample size of 108 .

\subsection{Sampling Techniques}

In this research, a convenience sampling was used with conjunction with purposive sampling. Selection of customers depended on their willingness and availability to partake in the study thus why convenient sampling was use because the customers do not come to the shop in any order. Anyone moves in any time and since the researchers will be only in the shop at certain hours of the day, it was best to use convenience sampling in order to get as many customers response as possible as they do their shopping.

However, purposive sampling was used to select the management of Melcom. The rationale was that, the management of Melcom was considered to have the right information on how; the wrapping of their items and facilities are designed to its customers.

Simple random sampling will also be employed to select employees of Melcom Ltd. The nature of the shop, which is working on shift basis; it was difficult to ensure every employee is represented in the sampling size. This brought in the need to sample employees who will present during the sampling day.

\subsection{Data Collection Tools/Instruments}

The tools employed in this study included questionnaires and interviews. The self-designed questionnaires for the study had six sections. Section A requested the respondents to provide their background information; Section $\mathrm{B}$ determine the elements of packaging that influences consumer buying decision; Section $\mathrm{C}$ investigate how packaging promotes the product of a company; and finally Section D To assess how packaging influences the prices of items; A self designed interview schedule will also be prepared to interview the management of the Melcom

\subsection{Data Collection Procedure}

The major source of data (primary data) was collected on packaging and consumer buying decision. First, a letter will be sent to Melcom Limited. Management to grant the permission to administer questionnaire and conduct interviews on their premises. Three types of questionnaires was administered to three types of respondents: customers, employees and management of the Melcom. Some questionnaires for the customers of the Melcom was self-administered and other questionnaire forms for employees will be handed over to management and methods adopted for their distribution.

In the first method, management spoke to the employees and then requested them to fill the questionnaires. The information from the management was collected through self designed interview schedule. The information from employees will be given to management for administration and collected later. Mode of their work in the shop, the researcher faced difficulties in collecting the information through personal interview. The best option use was self-administered method and collected back after the period of one month.

\subsection{Data analysis}

For good analysis and presentation of results, Microsoft Excel was used to analyse the data and also used to presented various charts to give a good pictorial interpretation of the analysis because of the image clarity. To achieve accuracy in the analysis, we analysed the questionnaires under their relative objectives. 


\subsection{RESULTS AND DICUSSIONS}

\subsection{Introduction}

This aspect of the paper focuses on the results and discussions. The analysis of the appraisal was put in sections in accordance to the objectives of study.

\subsection{Response Rate}

A total 109 questionnaires were administered to three categories of respondents: the management, staff and customers of Melcom. All the questionnaires were answered by respondents and returned to the researchers.

\subsection{Demographics Data}

From the analysis, most of the populations were made up of males consisting of 59 respondent representing $54.1 \%$ and the females were 50 in number representing $45.9 \%$.

In terms of age, the highest age group recorded was within the 18-25 year representing 38.0\%, 26-30 year representing $25.0 \%, 31-35$ year representing $21.0 \%$ and the lowest age group 36 and above representing $16.0 \%$.

\subsection{How Packaging Affects the cost of items}

The first specific aim of the paper was to explore the key factor(s) that influence consumer purchase decisions. Four key factors were examined (i.e. service quality, brand name, company network coverage and price). Questions 1 to 7 in the questionnaire relate to the causes that affect the cost of items which correspond with the first objective of the study. Table 4.1 shows the results from respondents on the subject.

Table 4.1 How Packaging can Influence Cost of Items

$H_{o}$ : Observed frequencies are equal to the expected frequencies

\begin{tabular}{|c|c|c|c|c|c|}
\hline \multirow{2}{*}{ Statement } & \multicolumn{3}{|c|}{ Response in frequency } & \multirow{2}{*}{$\begin{array}{l}\chi^{2} \\
d f(2)\end{array}$} & \multirow{2}{*}{ Interpretation } \\
\hline & Agree & Neutral & Disagree & & \\
\hline $\begin{array}{l}\text { Packaging serves as a means of price } \\
\text { differentiation. }\end{array}$ & $63(57.8 \%)$ & $35(32.1 \%)$ & $11(10.1 \%)$ & 37.4 & Significant \\
\hline $\begin{array}{l}\text { No company can increase the cost above that } \\
\text { of its competitors when their products are } \\
\text { identical. }\end{array}$ & $58(53.2 \%)$ & $23(21.1 \%)$ & $28(25.7 \%)$ & 85.74 & Significant \\
\hline $\begin{array}{l}\text { Manufacturers can increase cost of items if } \\
\text { their packaging is attractive and of good } \\
\text { quality. }\end{array}$ & $83(76.1 \%)$ & $24(22.0 \%)$ & $2(1.8 \%)$ & 96.57 & Significant \\
\hline $\begin{array}{l}\text { Firms can charge higher prices if their } \\
\text { packaging stress on the attributes of their } \\
\text { products. }\end{array}$ & $67(61.5 \%)$ & $26(23.9 \%)$ & $16(14.7 \%)$ & 40.21 & Significant \\
\hline $\begin{array}{l}\text { When products are distinct form others, } \\
\text { consumers would hardly switch to a different } \\
\text { product when there is an increase in price }\end{array}$ & $59(54.1 \%)$ & $33(30 \%)$ & $17(15.6 \%)$ & 24.75 & Significant \\
\hline $\begin{array}{l}\text { Poor packaging could decrease the prices of } \\
\text { top brands. }\end{array}$ & $80(73.4 \%)$ & $17(15.6 \%)$ & $12(11.0 \%)$ & 79.07 & Significant \\
\hline $\begin{array}{l}\text { Consumers will pay lower prices for products } \\
\text { with poor packages }\end{array}$ & $83(76.1 \%)$ & $15(13.8 \%)$ & $11(10.1 \%)$ & 90.13 & Significant \\
\hline
\end{tabular}

A one-way $\boldsymbol{\chi}^{2}$ test was used to analyze these data from the Table 4.1 above. We expected equal numbers of respondents (31) to respond to each category (Agree, Neutral, disagree). However observed frequencies were suggestively varied from expectations for all determinants assessed (packaging serves as a way of price differentiation, $\chi^{2}(2, N=109)=37.4, p<0.05$; no company can raise its price above that of its competitors when their products are identical, $\left.\chi^{2}(2, N=109)=85.74, p<0.05\right)$; company manufacturers can increase price if their packaging is attractive and of good quality, $\left.\chi^{2}(2, N=109)=96.57, p<0.05\right)$; firms can charge higher prices if their packaging stress on the attributes of their products, $\left.\boldsymbol{\chi}^{2}(2, N=109)=40.20, p<0.05\right)$; when products are distinct from others, consumers would hardly switch to a different product when there is an increase in price, $\left.\chi^{2}(2, N=109)=24.75, p<0.05\right)$; poor packaging could decrease the prices of top brands, $\chi^{2}(2$, 
$N=109)=79.07, \quad p<0.05)$; consumers will pay lower prices for products with poor packages, $\chi^{2}(2$, $N=109)=90.13, p<0.05)$.

Using descriptive statistics, the study found that $(57.8 \%)$ the packaging should be used as a means of price differentiation, while (10.1\%) said he wouldn't. In addition (53.2\%) stated that no company can increase its price higher than that of its competitors when their products are identical, while $(25.7 \%)$ said he wouldn't. Whether manufacturers can pay a higher price if their packaging is attractive and high quality, $(76.1 \%)$ indicated that it would be, while (1.8\%) Differences. In addition, companies may charge higher prices if their packaging maps the characteristics of the products they receive $(61.5 \%)$, while $(14.7 \%)$ and its packaging is strained by the characteristics of the products they receive $(61.5 \%)$, while $(14.7 \%)$ and their packaging is strained by the characteristics of the products they receive $(61.5 \%)$, while $(14.7 \%)$ and their packaging is strained by the characteristics of the products they receive (61.5\%), while ( Spirit. In addition $(54.1 \%)$ He said that when products are different, consumers are unlikely to switch to another product in case of price increases, while (15.6) say otherwise. Poor packaging can lower the prices of the best brands $(73.4 \%)$, while $(11.0 \%)$ not even. Finally, (76.1\%) said consumers will pay lower prices for products with bad packages, while $(4.6 \%)$ lower prices. said he wouldn't.

This means that, according to respondents, manufacturers who charge higher prices, if their packaging is attractive and of good quality, were an important factor in influencing the way packaging price of the product may affect, while consumers who pay lower prices for products, no company that raises its price higher than those of its competitors when their products are identical, poor packaging lowers the prices of the best brands, companies that charge prices higher if their Packaging highlights the characteristics of their products, packaging is a way to differentiate prices and for products that differ from other, consumers are unlikely to switch to another product when there is a price increase in this order if other factors affect how packaging can affect the price of the product. This finding argues (Silayoi s Speece, 2004), which found in a related study that when choosing multiple products, especially when consumers are more involved in the process, often choose the most expensive item because of the highest price higher quality.

\subsection{Elements of Packaging that Promotes the Produces of a Enterprise}

Question $8 \& 9$ in the questionnaire relate to the elements of packaging that promotes the products of a company which corresponds with the second objective of the study. These results are shown in Figures 4.1 and 4.2

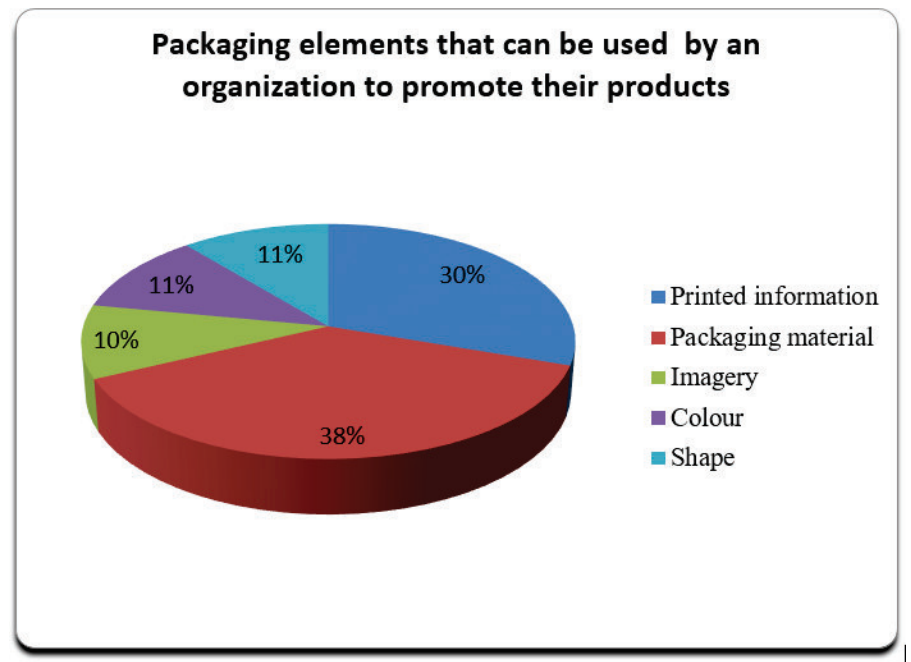

Source: Field Survey, July 2018

Fig 4.1 Results on respondents view on elements of packaging that can be used by an organization to promote their products

From the previous figure, forty-one (41) respondents representing $38 \%$ of the total number of surveys classified packaging material as the most important element that can be used by an organization to promote its products. Thirty-three (33) respondents representing 30\% of the total number of surveys classified printed information as the second most important element that can be used by an organization to promote its products. Twelve (12) respondents representing $11 \%$ of the total number of respondents ranked form and color as the third most important element. Once (11) respondents representing $10 \%$ of the images classified as the least important element that an organization can use to promote its products.

The results suggested that respondents preferred packaging material to images as an element that an organization can use to promote its products. The findings are in line with the studies by Burke (2006), Silayoi and Speece (2004) and Romaniuk and Gaillard (2007). For example, Burke (2006) selected the structure and 
materials of the packaging depending on several characteristics of the product itself, such as the type of product, the transport conditions, storage, protection, the target audience or the cost. However, Silayoi and Speece (2004) stated that when choosing between multiple products, especially when the consumer is more involved in the process, they will often choose the highest priced item because the higher price implies a higher quality (Silayoi and Speece, 2004 ) Romaniuk and Gaillard (2007) argue that packaging images can make a certain product look nice and attractive, but the actual product may not be as good as it shows once opened.

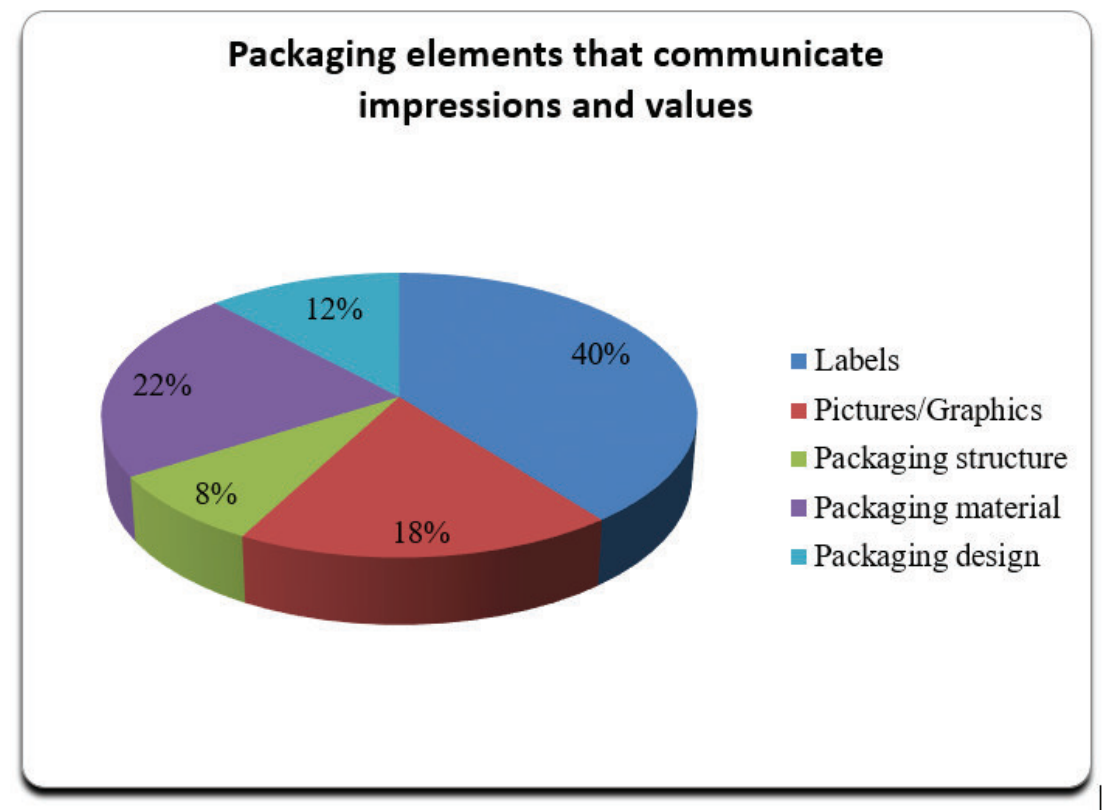

Source: Field Survey, July 2018

Fig 4.2 Results on respondents view on components of packaging elements that communicates certain impressions and values of the item at the time of purchase

From the figure above, 43 respondents representing $40 \%$ of respondents ranked Labels as the most important element that communicates certain impressions and values of the item at the time of purchase. 24 respondents representing $22 \%$ of the respondents ranked Packaging material as the most significant element. 20 respondents representing $18 \%$ of respondents ranked Pictures $\backslash$ Graphics as the third most important element. Followed by 13 respondents representing 12\% ranked Packaging design as the fourth most important element and 9 respondents representing $8 \%$ ranked Packaging structure as the least most important element that communicates certain impressions and values of an item at the time of purchase. The findings suggested that respondents preferred Labels to Packaging structure as an element that communicates certain impressions and values of the item at the time of purchase. These findings corroborate studies by Sharp (2006) and Burke (2006). For example Sharp (2006) emphasized that, for buyers exhibiting routine response behavior, the labels allow consumers to quickly locate the products they plan to purchase. For consumers who are buying in the first instances, they help establish brand identity and name recognition. . Packaging structure and materials depend on several characteristics of the product itself, such as, type of the product, transportation conditions, storage, protection, target audience, or cost (Burke, 2006).

\subsection{How Packaging Promotes the Items of a Company}

Question 10-18 in the questionnaire relates to how packaging promotes the items of a enterprise which corresponds with the third aim of the research. The second aim of the research is to examine whether consumer loyalty and trust is determined by service quality or brand name. Table 4.2 shows the outcomes from respondents on the subject. 
Table 4.2 How Packaging Promotes the Products of a Enterprise

$H_{o}$ : Observed frequencies are equal to the expected frequencies

\begin{tabular}{|c|c|c|c|c|c|}
\hline \multirow{2}{*}{ Statement } & \multicolumn{3}{|c|}{ Response in frequency } & \multirow{2}{*}{$\begin{array}{l}\chi^{2} D f \\
(2=5.990)\end{array}$} & \multirow{2}{*}{ Interpretation } \\
\hline & Agree & Neutral & Disagree & & \\
\hline $\begin{array}{l}\text { A package attracts a buyer's attention to } \\
\text { a specific brand, }\end{array}$ & $8880.7 \%)$ & $6(14.7 \%)$ & $4(3.7 \%)$ & 113.64 & Significant \\
\hline Packaging boosts the image of a product & $81(74.3 \%)$ & $1(19.3 \%)$ & $7(6.4 \%)$ & 85.08 & Significant \\
\hline $\begin{array}{l}\text { Packaging impacts the consumer's } \\
\text { opinions about a product. }\end{array}$ & $76(69.7)$ & $25(22.29 \%)$ & $8(7.3 \%)$ & 68.94 & Significant \\
\hline $\begin{array}{l}\text { Packaging effects distinctive cost to an } \\
\text { items }\end{array}$ & $85(78.0 \%)$ & $9(17.4 \%)$ & $5(4.6 \%)$ & 100.49 & Significant \\
\hline $\begin{array}{l}\text { Packaging helps consumers to select a } \\
\text { item from a varied collection of } \\
\text { dissimilar items }\end{array}$ & $7(70.6 \%)$ & $23(21.1 \%)$ & $9(8.3 \%)$ & 75.74 & Significant \\
\hline $\begin{array}{l}\text { A package influences the consumer's } \\
\text { purchase behaviour about product }\end{array}$ & $77(70.6 \%)$ & $26(23.9 \%)$ & $5(4.6 \%)$ & 75.48 & Significant \\
\hline $\begin{array}{l}\text { A good packaging leaves a positive } \\
\text { pictures of the items in the mind of the } \\
\text { consumer. }\end{array}$ & $89(81.7 \%)$ & $16(14.7 \%)$ & $4(3.7 \%)$ & 116.48 & Significant \\
\hline $\begin{array}{l}\text { Consumers are not inclined towards } \\
\text { product that comes in poor packages }\end{array}$ & $68(62.4 \%)$ & $23(21.1 \%)$ & $18(16.5 \%)$ & 41.75 & Significant \\
\hline $\begin{array}{l}\text { Packaging materials have negative } \\
\text { impact on the society }\end{array}$ & $66(60.6 \%)$ & $27(24.8 \%)$ & $16(14.7 \%)$ & 38.00 & Significant \\
\hline
\end{tabular}

Source: Field Survey, July 2018

Significance level: 0.05

A one-way $\chi^{2}$ test was used to analyze these data from the table 4.2 above. We expected equal numbers of respondents $(36.33 \%)$ to respond to each category (Agree, Neutral, Disagree). However observed frequencies were meaningfully dissimilar from expectations for all determinants assessed (a package attracts a buyer's attention to a specific brand, $\chi^{2}(2, N=109)=113.64, p<0.05$; packaging boosts the image of a product, $\chi^{2}(2$, $N=109)=85.08, p<0.05)$; packaging impacts the consumer's opinions about a product, $\boldsymbol{\chi}^{2}(2, N=109)=$ 68.94, $p<0.05)$; packaging conveys distinctive cost to products, $\left.\chi^{2}(2, N=109)=100.48, p<0.05\right)$; packaging helps consumers to select a item from a varied collection of similar products, $\left.\boldsymbol{\chi}^{2}(2, N=109)=75.74, p<0.05\right)$; a package influences the consumer's purchase behaviour about a product, $\left.\boldsymbol{\chi}^{2}(2, N=109)=75.48, p<0.05\right) ; a$ good packaging leaves a positive pictures of the items in the mind of the consumer, $\boldsymbol{X}^{2}(2, N=109)=116.48, p<$ $0.05)$; consumers are not inclined towards products that comes in poor packages, $\chi^{2}(2, N=109)=41.75, p<$ 0.05); Packaging materials have negative impacts on the environment, , $\left.\chi^{2}(2, N=109)=38.00, p<0.05\right)$.

Using the table above, the study found that (80.7\%) agreed that a package would attract a buyer's attention to a specific brand, whereas $(3.7 \%)$ said it would not. Furthermore, $(74.3 \%)$ agreed that packaging would boost the pictures of a produce, whereas (6.4\%) disagreed. As to whether packaging impacts the consumer's opinions about a product $(69.7 \%)$ stated that it would, whereas $(7.3 \%)$ objected. However, $(78.0 \%)$ mentioned that packaging give distinctive value to a product whilst, $(4.6 \%)$ disagreed. Moreover, $(70.6 \%)$ indicated that packaging helps consumers to select a goods from a varied collection of related items, whereas $(8.3 \%)$ were not in favour. In addition, (70.6\%) said that a package would influence the consumer's purchase behaviour about a product, while (4.6\%) objected. As to whether a good package would leave a positive I mage of the product in the mind of the consumer, $(81.7 \%)$ agreed, whereas $(3.7 \%)$ said otherwise. Consumers not being inclined towards a product that comes in a poor package received (62.4\%), whereas (16.5\%) disagreed. Finally, $(60.6 \%)$ also said packaging materials have negative impact on the environment, whereas $(14.7 \%)$ said it would not.

According to the respondents, a good package shows a positive picture of the elements in the minds of consumers was the main determinant of how packaging promotes a company's product. This supports Alexanders (2008) who states that packaging attracts a buyer's attention to a specific brand, strengthens its image and affects consumers' opinions about a product. 


\subsection{Conclusions}

Firstly, the study assessed how the packaging affects the cost of a product. The study found that manufacturers can raise prices if their packaging is attractive and of good quality. This will have an effect on the consumer's purchasing decision. It has also been found that defective packaging will have a substantial effect on the customer's purchase choice. In addition, it is understood that packaging does not serve as a way to differentiate the prices that have an effect on the purchase choice of the customer.

Secondly, the study determined the packaging elements that promote a company's product. These elements are (printed information, packaging material, images, color and shape, labels, images/images, packaging structure, packaging material and packaging design). The study showed that labels and printed material promote a company's assets and that these elements have an effect on the customer's purchase choice. It has also been noted that the images and packaging structure as packaging items cannot affect customer purchase choices. Thirdly, the research investigated how packaging promotes the product of a company. The outcomes indicated that a good packaging leaves a positive pictures of the items to the consumer.

\subsection{Recommendations}

Based on findings and conclusions of the study, the following are recommended to Melcom Limited and other major stakeholders. Manufacturing firms should note that the packaging influences the cost of a product, therefore they can increase the cost if their packaging is attractive and of good quality. They should also come out with innovative ways of making packaging more attractive and quality since it has an effect on customer purchasing choice.

Secondly, Melcom Limited and major stakeholders consider Labels and Packaging materials as elements of packaging that promotes the produces of a enterprise. Therefore Melcom Limited should stock their shops with products that will constantly provide their customers with quality Labels and Packaging materials in order to promote their enterprise. Melcom should give consideration to the Imagery and Packaging structure when stocking their shops with products, thus having an effect on buying decision.

Finally, Melcom Limited and major stakeholders should provide products with good packaging that will leave a positive image in the thoughts of the customers. Thus positive image in the thoughts of the customers will build brand loyalty.

\subsection{References}

Alice L. (2006). The Power of Packaging, United States of America, 188-216.

Bansah, F. P., Dabi M., Dzorvakpor, E. A. S., and Nwodo, H (2015). The Effect of Branding on consumer Buying Behaviour among Textile Ghana. European Journal of Business and Management, 5(26).

Barber, N., Almanza, B.A., \& Donovan, J.R. (2006). Motivational factors of gender, income and age on selecting a bottle of wine. International Journal of Wine Marketing, 18 (3), 218- 232.

Belch, G. E. \& Belch, M. E. (1999). Advertising and Promotion: An Integrated Marketing Communication Perspective $\left(4^{\text {th }}\right.$ ed $)$. McGraw Hill.

Deliya, M. M.,\& Parmar, J B. (2012). Role of Packaging on Consumer Buying Behavior. Global Journal of Management and Business Research, 12(10).

Foncel J. \& Ivaldi M. (2005). Operating System Prices in the Home PC Market. The Journal of Industrial Economics, 53 (2):265-297.

Gilaninia, S., Ganjinia, H., and Morad, S. (2013). Effect of Packaging Elements on Consumer Purchasing Decision. Universal Journal of Management and Social Sciences, 3(8).

Keller, Kevin L. (2008). Strategic Brand Management. New Jersey: Pearson Education.

Kotler, P., \& Armstrong, G. (2006). Principles of Marketing. New Jersey: Pearson Prentice Hall.

Krejice, R. V., \& Morgan, D., W. (1970). "Determining sample size for research activities" Educational and Psychological Measurement, 30(1970): 607-610

Panwar, J.S. (2004). "Beyond Consumer Marketing: Sectoral Marketing and Emerging Trends", Tejeshwar singh for response books, typeset in $10 \mathrm{pt}$, New Delhi.

Pride M William .Ferell O.C. (1997). Marketing Concepts \& Strategies, McGraw-Hill.

Reinartz W.J. and Kumar V., (2002) "The Mismanagement of Customer Loyalty.", Harvard Business Review, July, pp.86-94

Rettie, R., \& Brewer, C., 2000. The verbal and visual components of package design. Journal of Product Brand Management, 9 (1), 56-70.

Rita Kuvykaite, A.D. (2009). Impact of Package Elements on Consumer's Purchase Decision. Economics and Management, pp: 441-458.

Rundh, B. (2005). The multi-faceted dimension of packaging. British Food Journal, 107 (9), 670- 684.

Saeed, R., Lodhi, R.N., Rauf, A., Rana, M.I., Mahmood, Z., and Ahmed, N. (2013). Impact of Labelling on Customer Buying Behavior in Sahiwal, Pakistan. World Applied Sciences Journal 24 (9): 1250-1254. 
Silayoi, P., \& Speece, M. (2007). The importance of packaging attributes: a conjoint analysis approach. European Journal of Marketing, 41 (11/12), 1495-1517.

Underwood, R. L., Klein M. M., and Burke R. R. (2001). Packaging Communication: Attentional Effects of Products Imagery. J. Prod. Brand Manage. 10: 403-422.

Underwood, R. L. (2003). The communicative power of product packaging: Creating brand identity via lived and mediated experience. Journal of Marketing Theory and Practice, winter, 62-76.

Vila , N., \& Ampuero, O. (2007). The role of packaging in positioning an orange juice. Journal of Food Products Marketing, 13(3), 21-48.

Wells, L.E., Farley, H., \& Armstrong, G.A. (2007). The importance of packaging design for own-label food brands. International Journal of Retail \& Distribution Management, 35 (9), 677-690.

Young, S. (2006). Measuring Success: Using Consumer Research to Document the Value of Package Design. Design Management Review, 17(2), 60-65. 